HOW TO STUDY LITERATURE

General Editors: John Peck and Martin Coyle

HOW TO STUDY A SHAKESPEARE PLAY

Second Edition 


\section{IN THE SAME SERIES}

\section{How to Begin Studying English Literature* Nicholas Marsh How to Study a Jane Austen Novel Vivien Jones How to Study Chaucer Robert Pope How to Study a Joseph Conrad Novel Brian Spittles How to Study a Charles Dickens Novel Keith Selby How to Study an E. M. Forster Novel Nigel Messenger How to Study a Thomas Hardy Novel Fohn Peck How to Study a D. H. Lawrence Novel Nigel Messenger How to Study Milton David Kearns How to Study Modern Drama Kenneth Pickering How to Study Modern Poetry Tony Curtis}

How to Study a Novel* John Peck

How to Study a Shakespeare Play* John Peck and Martin Coyle How to Study a Poet Fohn Peck

How to Study a Renaissance Play Chris Coles How to Study Romantic Poetry Paul O'Flinn Literary Terms and Criticism* Fohn Peck and Martin Coyle Practical Criticism John Peck and Martin Coyle

*Now in a second edition

\section{Series Standing Order}

If you would like to receive future titles in this series as they are published, you can make use of our standing order facility. To place a standing order please contact your bookseller or, in case of difficulty, write to us at the address below with your name and address and the name of the series. Please state with which title you wish to begin your standing order. (If you live outside the UK we may not have the rights for your area, in which case we will forward your order to the publisher concerned.)

Standing Order Service, Macmillan Distribution Ltd, Houndmills, Basingstoke, Hampshire, RG21 2XS, England 


\title{
HOW TO STUDY A SHAKESPEARE PLAY
}

\section{Second Edition}

\author{
John Peck \\ and \\ Martin Coyle
}


All rights reserved. No reproduction, copy or transmission of this publication may be made without written permission.

No paragraph of this publication may be reproduced, copied or transmitted save with written permission or in accordance with the provisions of the Copyright, Designs and Patents Act 1988, or under the terms of any licence permitting limited copying issued by the Copyright Licensing Agency, 90 Tottenham Court Road, London W1P 9HE.

Any person who does any unauthorised act in relation to this publication may be liable to criminal prosecution and civil claims for damages.

First edition 1985

Reprinted five times

Second edition 1995

Published by

MACMILLAN PRESS LTD

Houndmills, Basingstoke, Hampshire RG21 2XS

and London

Companies and representatives

throughout the world

ISBN 978-0-333-64126-2

ISBN 978-1-349-13804-3 (eBook)

DOI $10.1007 / 978-1-349-13804-3$

A catalogue record for this book is available from the British Library.

$\begin{array}{llllllllll}10 & 9 & 8 & 7 & 6 & 5 & 4 & 3 & 2 & 1\end{array}$

$\begin{array}{llllllllll}04 & 03 & 02 & 01 & 00 & 99 & 98 & 97 & 96 & 95\end{array}$ 


\author{
For Matthew \\ and \\ Penny and Steven
}




\section{Contents}

General editors' preface $\quad$ ix

Preface $\quad$ xi

PART ONE

1 How to approach a Shakespeare play 3

2 Studying a history play 17

$\begin{array}{ll}\text { Richard II } & 17\end{array}$

Henry IV Part One $\quad 32$

Julius Caesar $\quad 41$

Antony and Cleopatra and Coriolanus $\quad 48$

3 Studying a tragedy $\quad 51$

Hamlet $\quad 53$

King Lear $\quad 68$

$\begin{array}{ll}\text { Othello } & 75\end{array}$

$\begin{array}{ll}\text { Macbeth } & 81\end{array}$

4 Studying a comedy $\quad 88$

Twelfth Night $\quad 91$

Much Ado About Nothing $\quad 104$

$\begin{array}{ll}\text { The problem comedies } & 113\end{array}$

$\begin{array}{ll}\text { The romances } & 115\end{array}$

5 Discussing an extract from a Shakespeare play 124

6 Writing an essay 141 
viii CONTENTS

PART TWO

7 New approaches to Shakespeare

8 Structuralism, poststructuralism and deconstruction $\mathbf{1 6 7}$

Richard II

Twelfth Night

9 Feminist criticism

Romeo and Fuliet

191

Much Ado About Nothing

10 New Historicism and Cultural Materialism

211

Julius Caesar

214

A Midsummer Night's Dream

11 Conclusion

237

The Tempest

238

Hamlet

Further reading

$A$ list of Shakespeare's plays 


\section{General editors' preface}

EVERYBODY who studies literature, either for an examination or simply for pleasure, experiences the same problem: how to understand and respond to the text. As every student of literature knows, it is perfectly possible to read a book over and over again and yet still feel baffled and at a loss as to what to say about it. One answer to this problem, of course, is to accept someone else's view of the text, but how much more rewarding it would be if you could work out your own critical response to any book you choose or are required to study.

The aim of this series is to help you develop your critical skills by offering practical advice about how to read, understand and analyse literature. Each volume provides you with a clear method of study so that you can see how to set about tackling texts on your own. While the authors of each volume approach the problem in a different way, every book in the series attempts to provide you with some broad ideas about the kind of texts you are likely to be studying and some broad ideas about how to think about literature; each volume then shows you how to apply these ideas in a way which should help you construct your own analysis and interpretation. Unlike most critical books, therefore, the books in this series do not simply convey someone else's thinking about a text, but encourage you and show you how to think about a text for yourself.

Each book is written with an awareness that you are likely to be preparing for an examination, and therefore practical advice is given not only on how to understand and analyse literature, but also on how to organise a written response. Our hope is that although these books are intended to serve a practical purpose, they may also enrich your enjoyment of literature by making you a more confident reader, alert to the interest and pleasure to be derived from literary texts. 


\section{Preface}

THE purpose of this book is to provide you with some broad guidelines about how to build a critical approach to a Shakespeare play. The book itself is divided into two parts. Part One is concerned with looking at the basic moves you can make to come to grips with a Shakespeare play: the first chapter explains how best to approach a play and how to begin shaping a critical response. The next three chapters then demonstrate how to construct a critical reading of the text by using a sequence of steps to build your argument. We look at how to tackle a history play, a tragedy and a comedy, in each case offering a number of examples that should allow you to see how the method applies to the particular play or plays you may be studying. After these chapters come two chapters which deal with how to discuss an extract from a Shakespeare play and how to write an essay.

Part One of the book is intended for students who are just getting started in criticism and are unsure about what is involved in studying a Shakespeare play. In Part Two, which is entirely new and appears for the first time in this 'Second Edition', we discuss some of the new approaches to Shakespeare. In recent years there has been a flood of new thinking in literary criticism, and a whole range of new critical approaches have appeared; students at university, in particular, soon become aware of terms such as deconstruction, feminist criticism and New Historicism. Part Two illustrates these new approaches in action, and suggests ways in which you can absorb this new thinking into your own work.

Part Two is at a more difficult level than the first part, and is intended to show you how you can take your studies on a stage further. By the end of the book, therefore, you might find th $\mathrm{ct}$ you are dealing with some unfamiliar ideas, but do try to see that the method is exactly the same as in the first part, that of building an analysis from the evidence in the text. This is because even the most innovatory approaches 
xii

PREFACE

are built upon close examination of the words on the page. And this, in essence, is the message of the book as a whole, that criticism starts from the close reading of the text.

University of Wales

Cardiff

JOHN PECK

MARTIN COYLE 